\title{
PENERAPAN ALGORITMA SEMUT PADA PROTOKOL ROUTING AOMDV UNTUK OPTIMASI PENCARIAN RUTE DI JARINGAN VANET
}

\author{
(Application of Ant Colony Optimization Algorithm to AOMDV Routing Protocol for \\ Optimization of Route Search on VANET)
}

\author{
Ni Desak Ketut Pujika Dewi', Andy Hidayat Jatmika, Ariyan Zubaidi \\ Dept Informatics Engineering, Mataram University \\ Jl. Majapahit 62, Mataram, Lombok NTB, Indonesia \\ Email: fujikadewi@gmail.com, [andy, ariyan.zubaidi]@unram.ac.id
}

\begin{abstract}
VANET is a derivative of the MANET network. VANET networks are more specifically used to communicate between one vehicle and another vehicle. With the existence of the VANET network, it is expected to be able to improve the safety of drivers on the highway. In the application of the VANET network, a routing protocol is needed. The AOMDV protocol is an example of a routing protocol that can help the performance of a VANET network. The purpose of this research is to optimize the route search in the AOMDV routing protocol. The route selection process in the AOMDV routing protocol is based on the least number of hops, so the route is likely to be disconnected quickly. To overcome the shortcomings of $A O M D V$ routing protocol, the ant colony optimization algorithm is applied. The advantage of an ant colony optimization algorithm is that in conducting a route search, performed by calculating the distance between nodes so that the route is not quickly interrupted. Selection of the route on the ant colony optimization algorithm based on the most pheromones, pheromones are ant footprints. The author modifies some of the frameworks of the AOMDV routing protocol section named AOMDV-ant. In the study conducted 5 experiments. The trial parameters used to assess network performance is throughput, packet delivery ratio (PDR), and average end-to-end delays. From the results of trials that have been carried out on the AOMDV routing protocol using the ant colony optimization algorithm, it can improve the performance of the test throughput parameters of $9.7649 \mathrm{Kbps}$ and the performance of the Packet delivery ratio of $11.2838 \%$. Whereas the average end to end delay parameter can reduce the delay by $13.3093 \mathrm{~ms}$.
\end{abstract}

Keywords: VANET, AOMDV, Algoritma Semut, Protokol Routing, Pencarian Rute

*Penulis Korespondensi

\section{Pendahuluan}

Vehicular Ad Hoc Network (VANET) merupakan salah satu jaringan wireless, jaringan ini merupakan turunan dari jaringan MANET. Jaringan VANET adalah suatu jaringan ad hoc yang dapat digunakan untuk berkomunikasi antar kendaraan satu dengan kendaraan lainnya [1]. Performa suatu jaringan ditentukan oleh kinerja protokol routing yang digunakan, routing ialah suatu proses yang dilakukan untuk menetukan rute dari node sumber ke node tujuan sehingga pada protokol routing inilah yang akan bertugas untuk menentukan suatu rute. Ad Hoc OnDemand Multipath Distance Vector (AOMDV) merupakan salah satu contoh dari protokol routing yang digunakan pada jaringan VANET.

Protokol routing AOMDV pada saat melakukan route discovery atau proses pencarian rute dari node sumber ke node tujuan dilakukan dengan mengirimkan paket RREQ (Route Request) ke node tetangganya. Jika paket RREQ telah diterima oleh node tujuan, maka node tujuan akan mengirimkan paket RREP (Route Reply) ke node sumber. Pada protokol routing AOMDV setiap melakukan proses RREP akan dipertimbangkan oleh node tujuan, sehingga beberapa path bisa ditemukan dalam satu proses pencarian rute [2]. Proses pemilihan rute pada protokol routing AOMDV dilakukan dengan mempertimbangkan jumlah hop pada rute tersebut. Jumlah hop yang paling sedikit yang akan digunakan untuk memilih rute pada protokol routing AOMDV. Kekurangan dari protokol routing AOMDV yaitu rute yang dipilih tidak memperhitungkan jarak antar node, sehingga dapat mengakibatkan rute tersebut memiliki kemungkinan terputus. Untuk mengatasi kekurangan dari protokol routing AOMDV tersebut diperlukannya sebuah metode. Algoritma semut merupakan salah satu metode yang digunakan untuk proses pencarian rute yang optimal. 
Algoritma semut (Ant Colony Optimization) merupakan algoritma yang diambil dari perilaku semut atau koloni semut untuk mencari makanan. Pada algoritma semut memperhitungkan jarak antar node, menghitung probabilitas untuk menentukan arah rute yang akan dituju sehingga lintasan semut dapat diketahui. Dalam algoritma semut terdapat istilah feromon yaitu jejak kaki semut yang melintasi rute, koloni semut dapat menemukan rute terpendek dengan mengikuti jejak kaki semut sebelumnya yang telah melintasi rute tersebut. Pada feromon tersebut dilakukan pembaharuan feromon (update feromon) untuk mendapatkan rute yang paling sering dilintasi oleh semut. Semakin banyak semut yang melewati rute tersebut maka semakin jelas feromon atau jejak kaki semut pada lintasan tersebut. Tujuan dari penelitian ini yaitu untuk menemukan proses pencarian rute yang optimal dengan menerapkan algoritma semut pada protokol routing AOMDV. Rute yang dipilih adalah berdasarkan jumlah feromon yang paling banyak yang dimiliki oleh algoritma semut, bukan lagi berdasarkan jumlah hop yang dimiliki oleh protokol routing AOMDV. Protokol routing yang telah dimodifikasi diberi nama AOMDV-Semut.

Oleh karena itu pada penelitian ini akan membandingkan kinerja dari protokol routing AOMDV standar dengan protokol routing AOMDV yang telah dimodifikasi dengan algoritma semut (AOMDV-Semut). Pemilihan peta pada penelitian ini yaitu mengambil peta jalan Kota Mataram, daerah tersebut dipilih karena memiliki karakteristik jalan persimpangan yang lebih dari satu. Simulasi dilakukan dengan menggunakan Network Simulator 2 (NS-2) versi 2.35, Java OpenSteetMap Editor (JOSM) dan Simulation of Urban Mobility (SUMO). NS2 merupakan perangkat lunak didesain secara spesifik untuk penelitian dalam bidang jaringan komunikasi komputer yang bersifat open source. JOSM merupakan aplikasi yang digunakan untuk meng-edit peta yang diperoleh melalui OpenStreetMap. SUMO merupakan aplikasi yang bersifat open source digunakan untuk membuat skenario mobilitas serta dapat diintegrasikan dengan OpenStreetMap untuk menetukan lokasi simulasi yang diinginkan. Parameter uji coba yang digunakan untuk menilai kinerja jaringan adalah throughput, Packet Delivery Ratio (PDR) dan End To End Delay.

\section{Tinjauan Pustaka}

Penelitian yang berjudul "Analisis Performansi Routing Protocol OLSR dan AOMDV pada Vehicular Ad Hoc Network (VANET)" [2] yaitu melakukan penelitian dengan membandingkan protokol routing OLSR dan
AOMDV di jaringan VANET. Setelah dilakukan simulasi dan analisa terhadap kedua algoritma routing protocol yaitu OLSR dan AOMDV, maka dapat diambil kesimpulan bahwa AOMDV lebih unggul hampir pada semua metrik performansi dengan nilai nilai rata-rata PDR $87.804 \%$, throughput 449.565 kbps, routing overhead 0.9773, dan NRL 1.1108. Sedangkan pada OLSR memiliki rata-rata PDR 83.539\%, throughput 427.735 kbps, routing overhead 1.4523, NRL 1.7436 . Pada metrik performansi End To End Delay OLSR lebih unggul dengan memiliki nilai rata-rata $4.765 \mathrm{~ms}$. Sedangkan pada AOMDV memiliki nilai $8.215 \mathrm{~ms}$. Karena AOMDV lebih unggul empat dari lima metrik performansi yang diujikan ini dapat menunjukkan bahwa protokol routing AOMDV lebih efisien diterapkan pada jaringan vehicular ad-hoc network (VANET) pada kondisi perkotaan.

Penelitian yang berjudul "Performance Improvement of Dynamic Source Routing (DSR) Protocol using Ant Colony Optimization for Vehicular Ad-hoc Network (VANET)" [3] yaitu melakukan analisis terhadap protokol routing DSR standar dengan protokol routing DSR yang telah dimodifikasi dengan menggunakan algoritma semut (DSR-Ant). Prameter uji coba yang dihitung yaitu Delay, jitter, konsumsi energi, routing load dan Packet Delivery Ratio. Hasil menunjukan bahwa DSR-Semut lebih unggul dibandingkan DSR standar dilihat dari metrik performasi Delay 2,25 ms, jitter 1,2 ms, routing load $0,36 \mathrm{Kbps}$, dan PDR 83,5\%. Sedangkan DSR standar hanya unggul pada metrik perfomansi konsumsi energi yaitu 15,75 joule.

Penelitian yang berjudul "Comparative Analysis of Various Routing Protocols in VANET" [4] yaitu melakukan penelitian dengan membandingkan kinerja dari protokol routing AODV, AOMDV, DSR dan DSDV di jaringan VANET. Parameter uji yang digunakan yaitu Delay, Packet Delivery Ratio, throughput, normalized routing load, packet loss. Hasil menunjukan bahwa protokol routing AOMDV memiliki kinerja yang baik dilihat dari PDR 98,55498\%, packet loss 1,4512\%, dan NRL 0,5558. DSR unggul pada metrik perfomasni Delay dan throughput yaitu $3,09288 \mathrm{~m} / \mathrm{s}$ dan $1833,24 \mathrm{Kbps}$. Dengan demikian dapat disimpulkan bahwa AOMDV lebih unggul dari hasil uji yang telah dilakukan, dilihat dari hasil uji PDR, packet loss dan NRL, sehingga ini dapat menunjukkan bahwa protokol routing AOMDV lebih efisien diterapkan pada jaringan vehicular ad-hoc network (VANET).

Penelitian yang berjudul "Ant Colony Optimization based Modified AOMDV for Multipath Routing in MANET" [5] yaitu menerapkan algoritma semut pada 
routing protokol AOMDV di jaringan MANET. Pada penelitian ini memodifikasi protokol routing AOMDV dengan menggunakan algoritma semut yang dimana menggunakan AODV-Ant sebagai perbandingannya. Hasil menunjukan bahwa protokol routing AOMDV-Ant lebih unggul dibandingkan AODV-Ant dilihat dari metrik perfomansi UDP data transmission analysis, UDP data Receives analysis, routing overhead, normalized routing load, Packet Delivery Ratio, dan no.of dropped data (packets) dengan nilai rata-rata sebesar 6694 Bps, 6325 Bps, 4088 Bps, 0,65, 94,49\%, 364 paket drop. Karena AOMDV-Ant unggul dari ke enam parameter uji yang telah dilakukan, dapat ditarik kesimpulan bahwa AOMDV-Ant memiliki kinerja yang lebih baik dibandingkan dengan AODV-Ant.

Penelitian yang berjudul "AODV Extension using Ant Colony Optimization for Scalable Routing in VANETS" [6] yaitu melakukan modifikasi protokol routing AODV dengan menggunakan algoritma semut. Penerapan optimasi koloni semut ke dalam protokol routing AODV digunakan untuk menentukan rute dan melakukan perbaikan jika terjadi kegagalan rute. Modifikasi AODV dengan algoritma semut dapat mengurangi routing overhead dan meningkatkan kinerja dengan menghindari kegagalan rute yang sering terjadi.

\section{Metode Penelitian}

\subsection{Alur Penelitian}

\subsubsection{Studi Literatur}

Pada penelitian ini dilakukan pembelajaran terhadap penelitian-penelitian terkait yang telah dilakukan sebelumnya sebagai dasar dalam melakukan penelitian yang akan dilakukan. Sumber penelitian sebelumnya dapat berupa paper, skripsi, tesis, maupun buku yang dapat menunjang serta mempermudah penelitian yang akan dilakukan.

\subsubsection{Mempesiapkan Hardware dan Software}

Pada bagian ini, perlu mempersiapkan baik perangkat keras maupun perangkat lunak yang akan digunakan pada penelitian ini. Perangkat keras yang digunakan seperti laptop dan perangkat lunak yang digunakan seperti Network Simulator 2 (NS2), Simulation of Urban Mobility (SUMO), Java OpenStreetMap (JOSM) dan Microsoft Office Excel.

\subsubsection{Melakukan Pemilihan Peta}

Pada tahap ini, peneliti melakukan proses pemilihan peta, penelitian ini menggunakan peta Kota
Mataram khususnya jalan yang terhubung antara Jl. Pejanggik, Jl. Catur Warga, Jl. Panca Usaha, Jl. Bung Karno, Jl. Sriwijaya Majapahit. Peta jalan dapat dilihar dari website http://openstreetmap.org. Hasil dari proses ini berupa peta daerah Kota Mataram yang telah dipilih dengan format .osm.

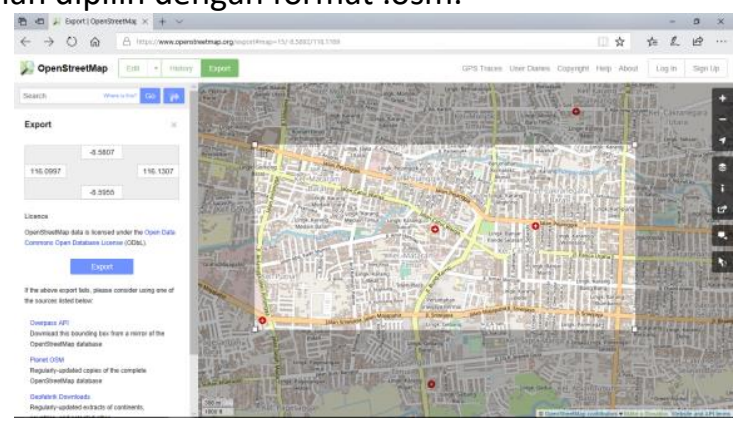

Gambar 1. Pemilihan lokasi peta melalui openstreetmap

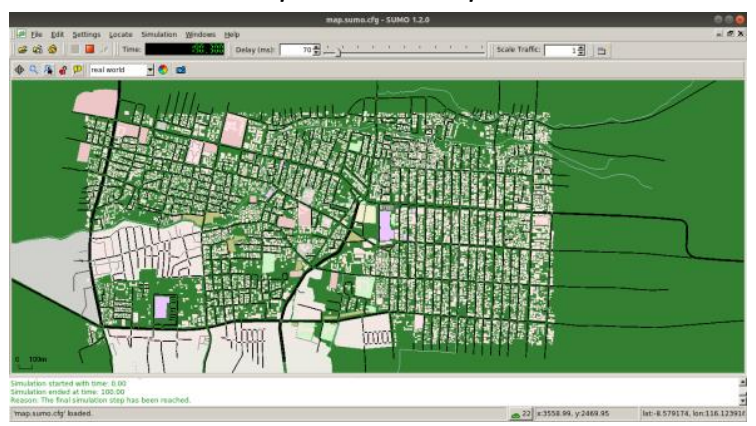

Gambar 2. Simulasi jaringan lalu lintas pada SUMO : mode real world

\subsubsection{Membuat Script Algoritma Semut pada Protokol Routing AOMDV}

Pada tahap ini, dilakukan modifikasi script pada protokol AOMDV dengan menggunakan algoritma semut. Modifikasi ini diharapkan dapat mengoptimalkan kinerja protokol AOMDV dalam melakukan pencarian rute pada jaringan VANET. Modifikasi yang dilakukan yaitu dengan melakukan perubahan pada proses route discovery AOMDV.

\subsubsection{Membuat Script Simulasi VANET}

Pada tahap ini dilakukan perancangan simulasi jaringan yaitu pada jaringan VANET. Dalam membuat script simulasi jaringan digunakan bahasa pemerograman TCL (Tool Command Language). Bahasa pemerograman TCL merupakan bahasa pemerograman yang berdasarkan pada string.

\subsubsection{Filtering File Trace}

Pada tahap ini didapatkan hasil simulasi jaringan dengan menggunakan NS-2 dan menghasilkan file trace (.tr). Setelah itu dilakukan filtering terhadap file trace dengan menggunakan bahasa pemrograman 
AWK. Kemudian hasil filtering dari file trace berupa parameter uji. Parameter uji yang digunakan yaitu :

a. Throughput : suatu istilah yang mendefinisikan banyaknya bit yang diterima dalam selang waktu tertentu. Secara umum throughput dinyatakan dalam persamaan 1 dengan rumus sebagai berikut [7]:

$$
\text { Throughput (Kbps) }=\frac{\text { Spaket data diterima }}{\sum \text { waktu }}
$$

b. Average end-to-end Delay: waktu yang dibutuhkan untuk melakuka pengiriman paket data dari node sumber ke node tujuan [8]. Average end-to-end Delay dihitung menggunakan persamaan 2 dengan rumus sebagai berikut :

Average Delay $(\mathrm{m} / \mathrm{s})=\frac{\text { Total Delay }}{\text { Total paket yang diterima }}$

c. Packet Delivery Ratio (PDR) : perbandingan antara paket data yang berhasil diterima oleh node tujuan dengan total paket data yang dikirimkan oleh node sumber[8]. PDR dihitung menggunakan persamaan 3 dengan rumus sebagai berikut :

PDR (\%) $=\frac{\text { Paket data diterima }}{\text { Paket data dikirim }}$

\subsubsection{Membuat Grafik Hasil Simulasi}

Pada tahap ini nilai yang didapatkan setelah dilakukan filtering file trace kemudian dibuat dalam bentuk grafik agar memudahkan dalam melakukan analisis. Dalam membuat grafik hasil uji coba simulasi dengan mengguanakan Microsoft Excel, dimana datanya diperoleh dari proses filtering dari file trace yang berisikan parameter uji.

\subsubsection{Menganalisis Hasil Simulasi}

Pada tahap ini dilakukan proses analisis terhadap hasil yang diperoleh dari penelitian yang dilakukan. Hasil yang diperoleh untuk mengetahui mengetahui bagaimana pengaruh algoritma semut pada protokol AOMDV dalam jaringan VANET. Script AWK digunakan untuk menganalisis parameter uji kinerja yang menjadi acuan yaitu throughput, Average End To End Delay dan Packet Delivery Ratio. Jika hasil yang diperoleh tidak sesuai memenuhi kualitas kinerja yang baik yang ditentukan dari parameter uji maka akan dilakukan perancangan simulasi kembali.

\subsubsection{Membuat Kesimpulan}

Pada tahap ini akan dilakukan penarikan kesimpulan terhadap penelitian yang telah dilakukan. Penarikan kesimpulan dilakukan agar dapat mengetahui kelebihan dan kekurangan dari suatu penelitian, sehingga kinerja protokol routing AOMDV dengan algoritma semut di jaringan VANET dapat diketahui.

\subsubsection{Membuat Laporan}

Pada tahap ini membuat laporan atau dokumentasi terhadap penelitian yang dilakukan. Dokumentasi laporan ini diharapkan agar dapat membantu dalam penelitian berikutnya yang berkaitan dengan penelitian yang dilakukan.

\subsection{Protokol Routing AOMDV}

Protokol routing AOMDV (Ad Hoc On-Demand Multipath Distance Vector Routing) adalah protokol routing yang bersifat reaktif yang merupakan pengembangan dari protokol routing AODV. AOMDV juga menyediakan dua mekanisme kerja yaitu route discovery dan maintenance. Pada protokol routing AOMDV berbasis vektor dan menggunakan pendekatan hop-by-hop. AOMDV juga hanya melakukan pencarian rute ketika dibutuhkan dengan menggunakan prosedur route discovery.

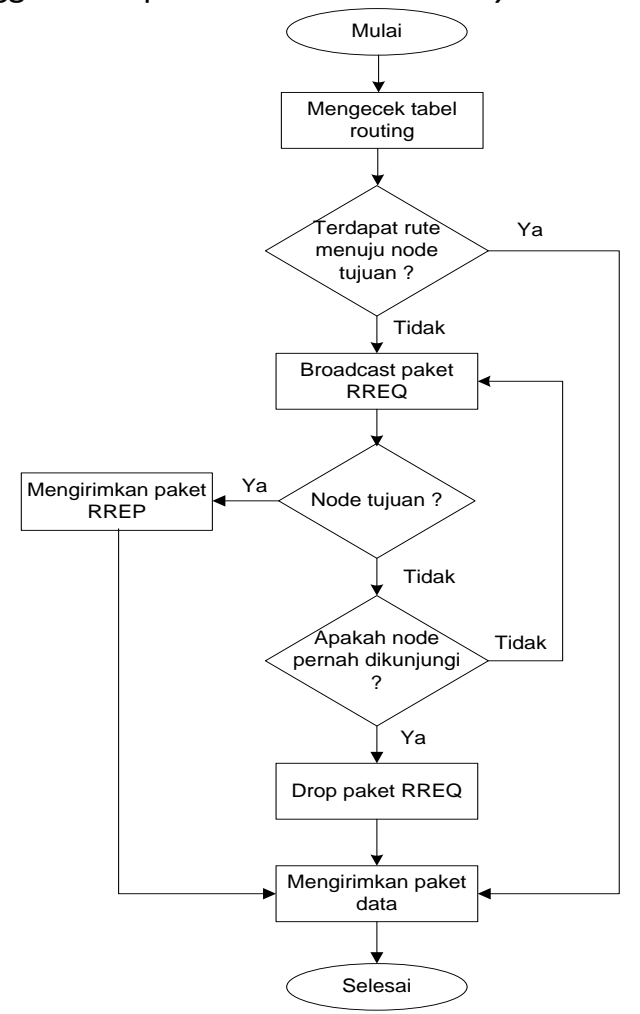

Gambar 3. Diagram alir route discovery AOMDV

Proses pencarian rute pada protokol routing AOMDV ketika node sumber memerlukan rute untuk mengirimkan paket ke node tujuan. Node sumber akan memeriksa pada tabel routing terlebih dahulu untuk 
mengirimkan paket data menuju node tujuan. Jika rute tersedia maka akan dipilih rute terdekat berdasarkan jumlah hop terkecil untuk mengirimkan paket data. Jika tidak ada maka akan dilakukan pencarian rute dengan cara mem-broadcast paket RREQ node terdekatnya dan melakukan set up reverse path. Setiap node yang dikunjungi akan diperiksa terlebih dahulu sebelum melanjutkan broadcast RREQ. Jika node yang dikunjungi merupakan node tujuan, maka akan dilakukan pengiriman RREP melalui reverse path yang sudah di set up sebelumnya. Jika bukan node tujuan maka akan dicek kembali apakah node tersebut sudah pernah dikunjungi sebelumnya. Jika pernah dikunjungi, maka paket RREQ akan di drop. Jika belum pernah dikunjungi, maka proses broadcast RREQ akan dilanjutkan sampai node tujuan ditemukan.

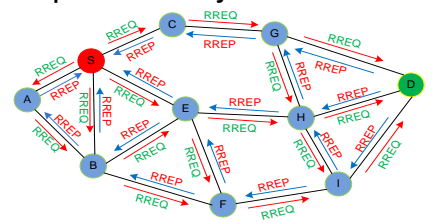

Gambar 4. Ilustrasi route discovery AOMDV

Proses pencarian rute pada protokol routing AOMDV. Node S akan mengirimkan paket data ke node $\mathrm{D}$, karena pada tabel routing node $\mathrm{S}$ tidak terdapat rute cadangan ke node $\mathrm{D}$, maka node harus mem-broadcast paket RREQ ke node-node disekitarnya untuk menemukan rute menuju node $\mathrm{D}$. Node $\mathrm{S}$ membroadcast paket RREQ ke node $\mathrm{A}, \mathrm{B}, \mathrm{C}$ dan $\mathrm{E}$, kemudian node $\mathrm{A}, \mathrm{B}, \mathrm{C}, \mathrm{E}$ juga akan mem-broadcast paket RREQ ke node-node tetangga mereka masing-masing hingga sampai di node D. Node-node yang berada diantara node $\mathrm{S}$ dan node $\mathrm{D}$ merupakan intermediate node yang akan melakukan set up reverse path untuk mengingat node-node yang telah dilewati untuk mencapai node D. Selanjutnya, node D akan mengirimkan paket RREP sebagai balasan dari paket RREQ ke node $S$ secara unicast melalui masing-masing rute. Dengan demikian, diperoleh empat rute, yakni $\mathrm{S} \rightarrow \mathrm{A} \rightarrow \mathrm{B} \rightarrow \mathrm{F} \rightarrow \mathrm{I} \rightarrow \mathrm{D}$, $\mathrm{S} \rightarrow \mathrm{B} \rightarrow \mathrm{F} \rightarrow \mathrm{I} \rightarrow \mathrm{D}, \mathrm{S} \rightarrow \mathrm{C} \rightarrow \mathrm{G} \rightarrow \mathrm{D}$ dan $\mathrm{S} \rightarrow \mathrm{E} \rightarrow \mathrm{H} \rightarrow \mathrm{D}$. Rute yang terpilih adalah rute yang memiliki jumlah hop terkecil, yakni rute $\mathrm{S} \rightarrow \mathrm{C} \rightarrow \mathrm{G} \rightarrow \mathrm{D}$ dan $\mathrm{S} \rightarrow \mathrm{E} \rightarrow \mathrm{H} \rightarrow \mathrm{D}$. Sedangkan, rute yang tidak terpilih akan dijadikan rute cadangan.

Gambar 5. ilustrasi route maintenance AOMDV

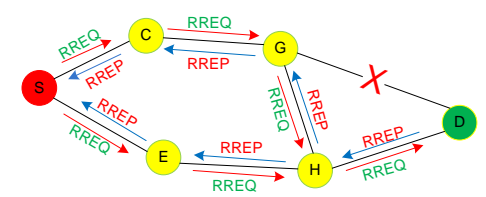

Dimana pada saat terjadi kegagalan rute, maka akan dikirim paket Route Error (RERR), jika terdapat jalur yang rusak, protokol AOMDV akan memilih rute cadangan (multipath) apabila ada, kemudian node sumber akan kembali melakukan pencarian rute.

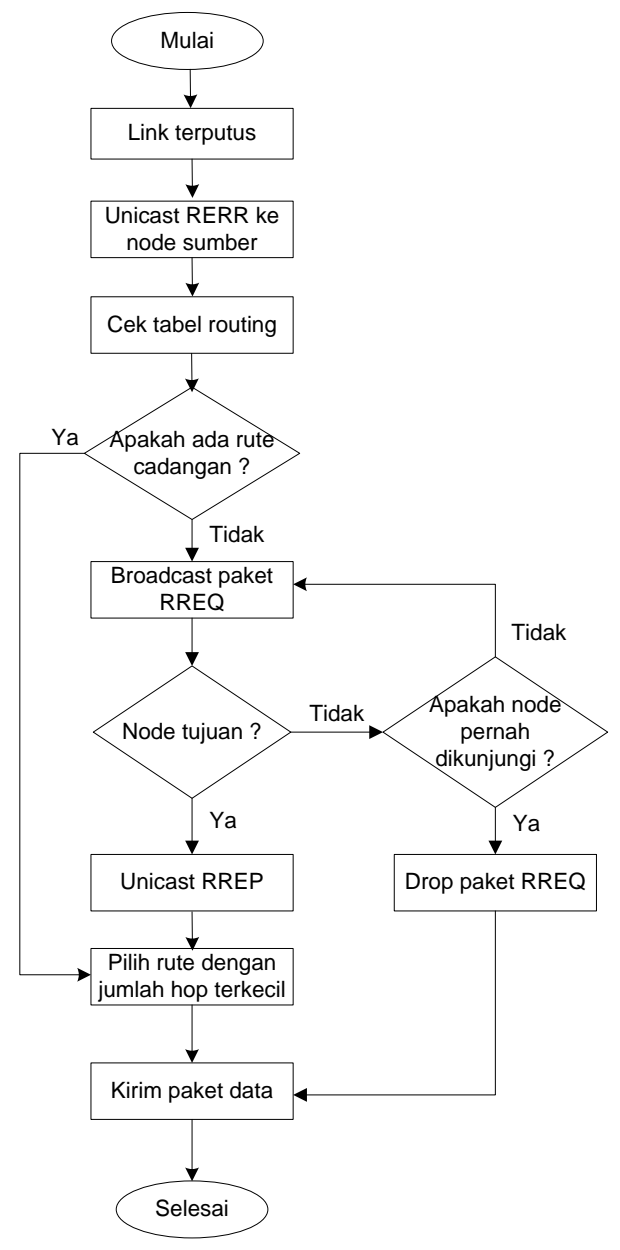

Gambar 6. Diagram alir route maintenance AOMDV

Proses route maintenance dari ptotokol routing AOMDV. Route maintenance merupakan proses pemeliharaan rute. Node akan mengirimkan RERR (Route Error) ke node sumber secara unicast jika link yang menghubungkan antara node sumber dan node tetangganya terputus. Kemudian tabel routing node sumber akan di cek, apakah terdapat rute cadangan ke node tujuan yang sama. Jika ada, maka rute dengan jumlah hop terkecil akan dipilih dan paket data dapat langsung dikirimkan. Namun, apabila tidak terdapat rute cadangan, maka akan dilakukan proses route discovery.

\subsection{Algoritma Semut}

Algoritma semut merupakan algoritma yang terinspirasi oleh perilaku semut dalam menemukan rute dari sarang menuju sumber makanan. Semut mampu mengindra lingkungannya yang kompleks mencari makanan dan kemudian kembali ke sarangnya dengan meninggalkan zat feromon pada jalur-jalur 
yang mereka lalui. Dengan adanya feromon inilah semut dapat menemukan jalur tercepat menuju sumber makanan. Feromon merupakan zat kimia yang berasal dari kelenjar endokrin dan digunakan oleh makhluk hidup untuk mengenali sejenisnya (satu spesies). Pada semut meninggalkan jejak kaki untuk sebagai penanda untuk mengingat jalan pulang maupun berkomunikasi dengan koloninya [10].

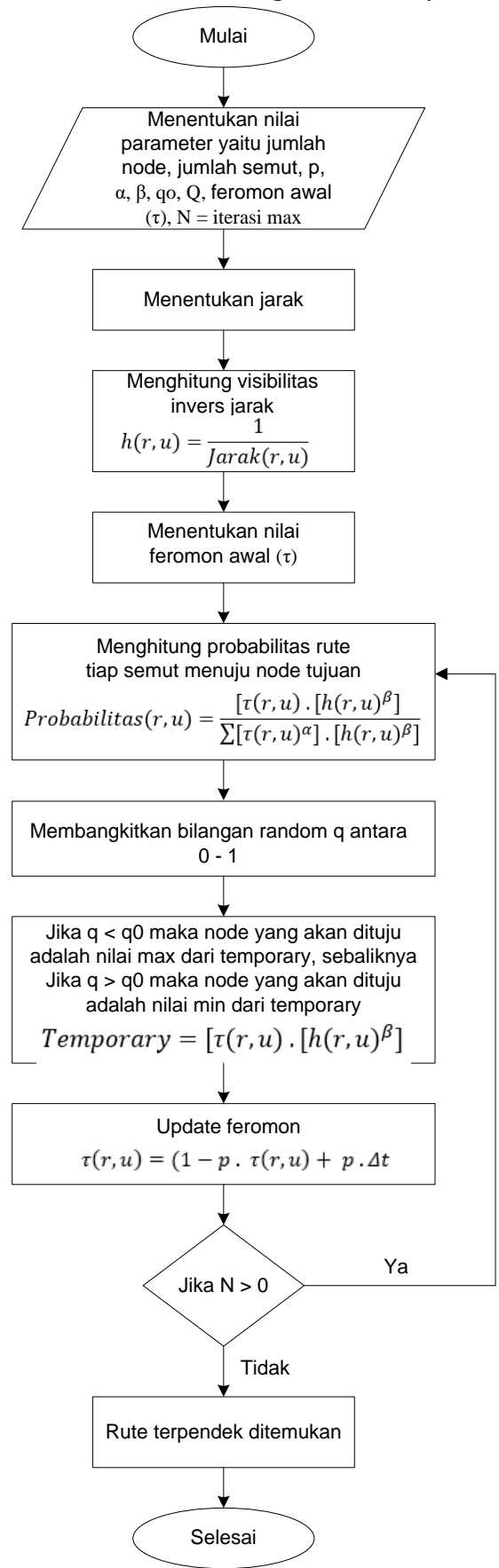

Gambar 7. Diagram alir proses algoritma semut

Pada Gambar 7 merupakan proses kerja dari algoritma semut. Adapun tahap-tahap yang dilakukan yaitu:
1. Tahap pertama yaitu menentukan atau menginisialisasikan nilai parameter awal, parameter-parameter tersebut adalah [7] [9]:

a. Banyak node atau jumlah node

b. Banyak semut

c. Tetapan siklus-semut (Q)

d. Tetapan pengendali intensitas jejak semut $(\alpha)$, nilai $\alpha \geq 0$

e. Tetapan pengendali visibilitas $(\beta)$, nilai $\beta \geq 0$

f. Tetapan penguapan jejak semut $(\rho)$, nilai $\rho$ harus $>0$ dan $<1$ untuk mencegah jejak feromone yang tak terhingga.

g. Parameter perbandingan eksploitasi terhadap eksplorasi (q0)

h. Nilai feromon awal $(\tau)$

2. Kemudian memperhitungkan koordinat $(x, y)$ atau jarak antar node untuk mengetahui jarak node satu dengan node lainnya.

3. Setelah semut di inisialisaikan kemudian semut ditempatkan pada node pertama tertentu secara acak. Semut ini disebut paket forward ant, karena akan menelusuri rute hingga ke node tujuan. Ketika sudah menemukan node tujuan, semut ini akan kembali melewati rute yang sama. Pada kondisi ini semut tersebut disebut backward ant.

4. Selanjutnya yaitu menghitung invers jarak atau visibilitas antar node yang akan dilakukan pengisian kedalam tabu list yang berisikan informasi dari visibilitas antar node. Dapat dilihat pada persamaan 4 yaitu sebagai berikut [9]:

$h(r, u)=\frac{1}{\operatorname{Jarak}(r, u)}$

5. Menentukan nilai feromon awal dan memasukkannya kedalam tabu list. Nilai dari semua feromon $(\tau)$ pada awal perhitungan ditetapkan dengan angka awal yang sangat kecil [8], misal 0.001.

6. Selanjutnya menghitung probabilitas rute tiap semut menuju node tujuan. Koloni semut yang sudah terdistribusi ke sejumlah atau setiap node, akan mulai melakukan perjalanan dari node pertama masing-masing sebagai node asal dan salah satu node lainnya sebagai node tujuan. Untuk menentukan node tujuan dapat dilihat pada persamaan 5 yaitu sebagai berikut [9]:

$\operatorname{Prob}(r, u)=\frac{\left[\tau(r, u) \cdot\left[h(r, u)^{\beta}\right]\right.}{\sum\left[\tau(r, u)^{\alpha}\right] \cdot\left[h(r, u)^{\beta}\right]}$

7. Membangkitkan bilangan random q yaitu koloni semut akan melanjutkan perjalanan dengan memilih salah satu dari node - node yang tidak terdapat pada tabu list sebagai node tujuan selanjutnya. Perjalanan koloni semut berlangsung 
terus menerus sampai semua node satu persatu dikunjungi atau telah menempati tabu list.

8. Membandingkan nilai dari bilangan random $\mathrm{q}$ dengan bilangan q0 yang telah ditetapkan diawal. Jika q>q0 maka node selanjutnya yang dipilih adalah nilai temporary yang paling kecil, jika $\mathrm{q}<\mathrm{q0}$ maka node selanjutnya yang dipilih adalah nilai temporary yang paling besar. Dapat dilihat pada persamaan 6 yaitu sebagai berikut [9]:

$$
\text { Temporary }=\left[\tau(r, u) \cdot\left[h(r, u)^{\beta}\right]\right.
$$

9. Setelah rute dari semut 1 hingga ke-n dari siklus pertama ditemukan, maka dilakukan pembaharuan feromon atau update feromon. Koloni semut akan meninggalkan jejak-jejak kaki pada lintasan antar node yang dilaluinya. Adanya penguapan dan perbedaan jumlah semut yang lewat, menyebabkan kemungkinan terjadinya perubahan harga intensitas jejak kaki semut antar node. Dapat dilihat pada persamaan 7 yaitu sebagai berikut [9]:

$\tau(r, u)=(1-p \cdot \tau(r, u)+p \cdot \Delta t$

$\Delta t$ adalah perubahan harga intensitas jejak kaki semut antar node setiap semut yang dihitung berdasarkan persamaan 8 [9] :

$$
\Delta t=\frac{Q}{L k}
$$

Lk merupakan panjang jarak dari rute yang telah ditemukan.

10. Lakukan ulang langkah 6 hingga iterasi atau perulangan selesai, sehingga rute terpendek dapat ditemukan dengan menilai dari banyak feromon yang dilalui semut pada rute tersebut.

\subsection{Penerapan Algoritma Semut pada Protokol Routing AOMDV}

Pada protokol routing AOMDV mempunyai tujuan yang sama dengan algoritma semut yaitu sama-sama mencari rute yang paling optimal dari node sumber ke node tujuan. Pada algoritma semut memiliki dua mekanisme kerja yaitu forward ant dan backward ant. Forward ant sama halnya dengan paket RREQ pada protokol routing AOMDV dan backward ant sama halnya dengan paket RREP pada protokol routing AOMDV. Penerapan pada routing jaringan, sarang semut merupakan node sumber dan sumber makanan adalah node tujuan.

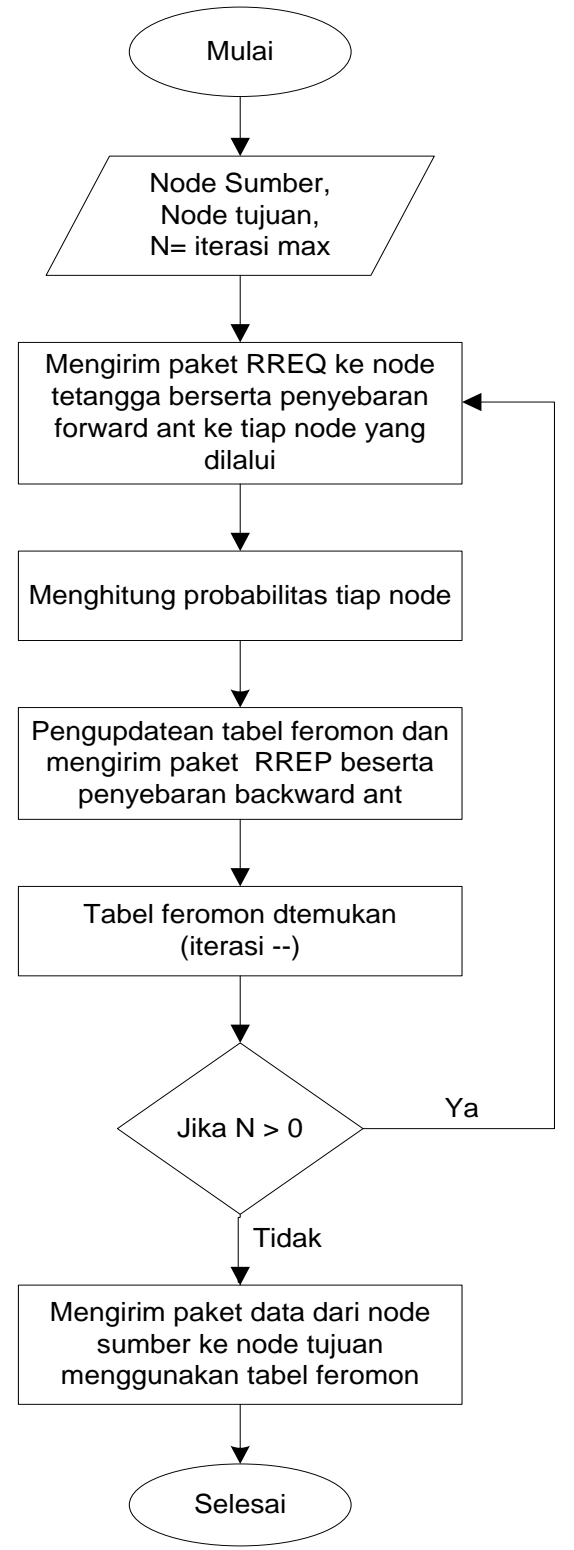

Gambar 8. Diagram alir proses AOMDV-Semut

\section{Hasil dan Pembahasan}

Berdasarkan ujicoba yang dilakukan pada penelitain ini untuk menilai kinerja dari protocol routing AOMDV yang digunakan dibutukannya suatu parameter ujicoba Berikut ini merupakan analisis dari parameter ujicoba yang digunakan pada penelitan :

\subsection{Analisis Throughput}

Throughput merupakan ukuran kecepatan yang diterima dari node sumber ke node tujuan. Throughput dapat dikatakan baik dilihat dari kinerja pengiriman data yang tinggi dari node sumber ke node tujuan. Berdasarkan seluruh ujicoba yang telah dilakukan pada percobaan AOMDV standar, dapat diketahui bahwa 
pada parameter throughput nilai yang di peroleh relative tinggi, Hal ini dikarenakan sifat reaktif yang dimiliki oleh protokol AOMDV, sehingga pencarian rute hanya dilakukan ketika rute dari node sumber ke node tujuan tidak terdapat di dalam tabel routing. Adanya penambahan jumlah menyebabkan nilai throughput pada protokol AOMDV mengalami peningkatan, hal ini disebabkan semakin banyak node yang terdapat pada lingkungan simulasi maka lingkungan simulasi akan semakin padat sehingga semakin kecil kemungkinan terjadinya link terputus pada jalur komunikasi dan menyebabkan daya tahan link menjadi lebih lama. Kondisi ini bebanding terbalik dengan adanya penambahan kecepatan node, semakin tinggi mobilitas node maka semakin rendah nilai throughput yang dihasilkan, karena semakin tinggi mobilitas maka setiap node maka pergerakan node akan semakin cepat, sehingga link yang sebelumnya telah terbentuk akan semakin cepat putus, sehingga untuk dapat mengirimkan paket dari sumber ke tujuan diperlukan proses broadcast kembali.

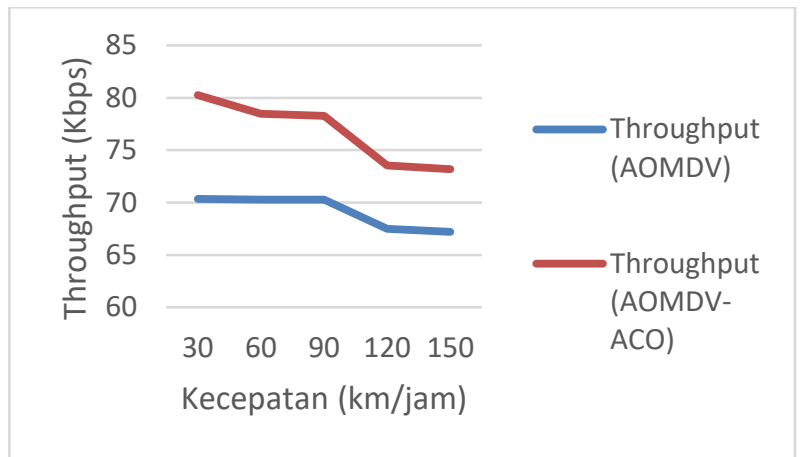

Gambar 9. Grafik Throughput 50 Node

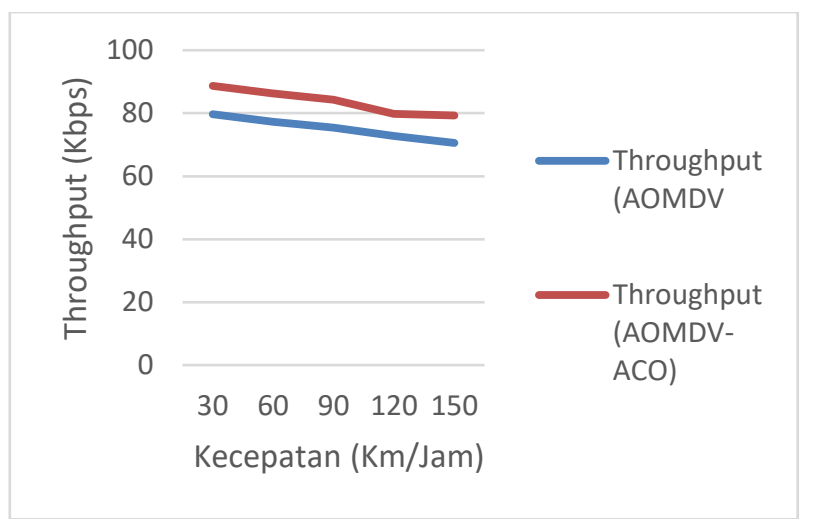

Gambar 10. Grafik Throughput 70 Node

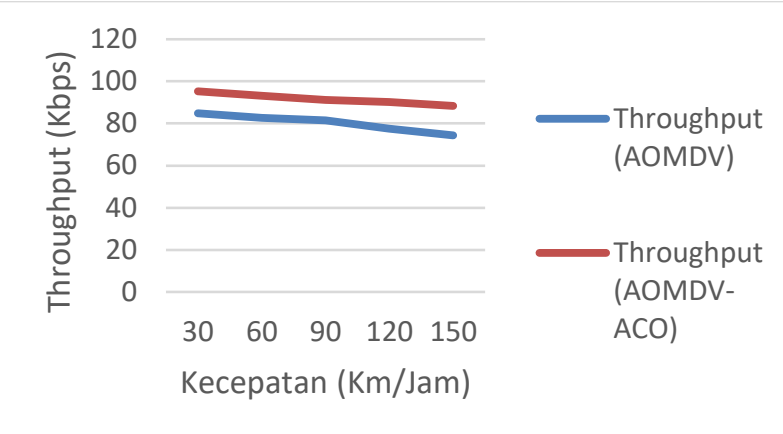

Gambar 11. Grafik Throughput 100 Node

Perbandingan nilai throughput pada node 50, 70 dan 100 yaitu berdasarkan grafik Gambar 9, Gambar 10 dan Gambar 11. Pada percobaan tersebut menunjukan hasil bahwa protocol routing AOMDV yang telah dimodifikasi dengan algoritma semut lebih baik dibandingkan AOMDV standar. Dapat dilihat dari nilai nilai rata-rata yang diperoleh throughput pada protokol routing AOMDV tanpa modifikasi dengan 50 node yaitu sebesar $69.11256 \mathrm{Kbps}$. Untuk nilai rata-rata throughput pada protokol routing AOMDV-semut dengan 50 node yaitu sebesar $76.7503 \mathrm{Kbps}$. Adapun selisih rata-rata yang diperoleh antara AOMDV standar dengan AOMDV-Semut pada parameter throughput pada 50 node yaitu sebesar 7.63774Kbps. Sedangkan nilai rata-rata throughput protokol routing AOMDV standar pada 70 node yaitu sebesar $75.1384 \mathrm{Kbps}$. Untuk nilai rata-rata throughput protokol routing AOMDV-semut pada 70 node yaitu sebesar $83.6689 \mathrm{Kbps}$. Adapun selisih rata-rata yang diperoleh antara AOMDV standar dengan AOMDV-Semut pada 70 node yaitu sebesar $10.2366 \mathrm{Kbps}$. Kemudian nilai rata-rata throughput protokol AOMDV standar pada 100 node yaitu sebesar $80.20694 \mathrm{Kbps}$. Dan nilai ratarata throughput protokol routing AOMDV-semut pada 100 node yaitu sebesar $91.62742 \mathrm{Kbps}$. Adapun selisih rata-rata yang diperoleh pada parameter throughput antara AOMDV standar dengan AOMDV-Semut pada 100 node yaitu sebesar $11.42048 \mathrm{Kbps}$. Sehingga jika dirata-ratakan secara keseluruhan AOMDV semut mampu meningkatkan nilai throughput sebesar 9.7649 Kbps.

\subsection{Analisis Average End-to-End Delay}

Average End To End Delay merupakan waktu yang diperlukan untuk mengirimkan paket dari node sumber menuju node tujuan. Semakin sedikit waktu yang dibutuhkan maka semakin bagus kinerja dari protocol routing tersebut. 


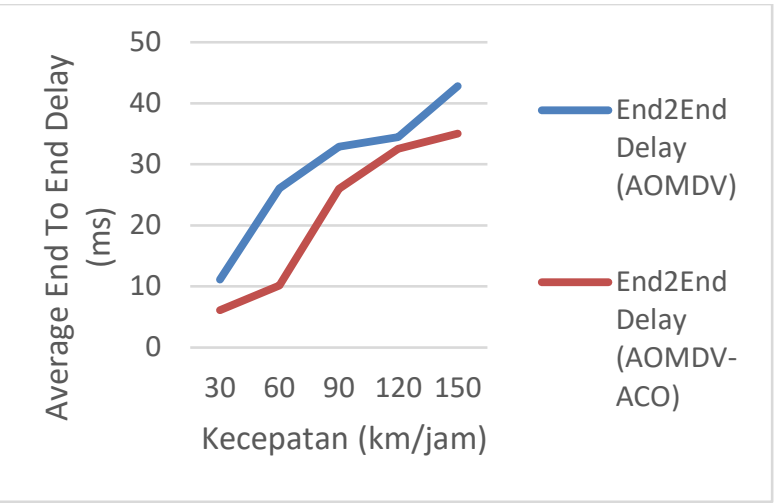

Gambar 12. Grafik Delay 50 Node

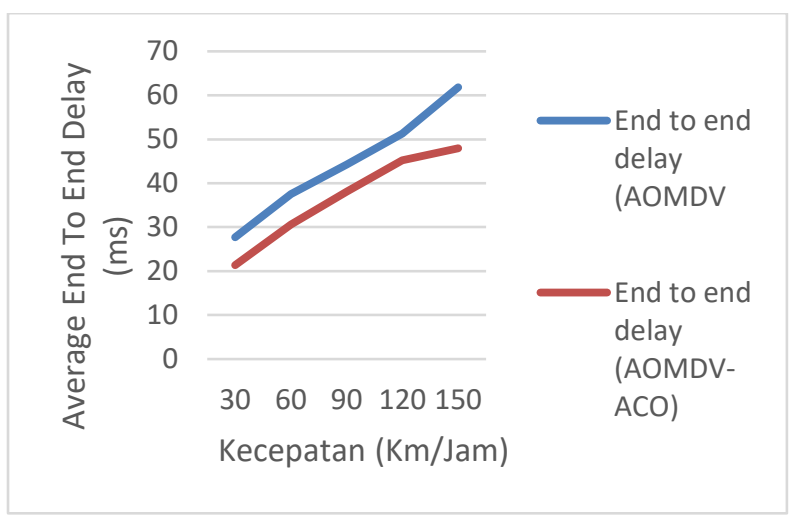

Gambar 13. Grafik Delay 70 Node

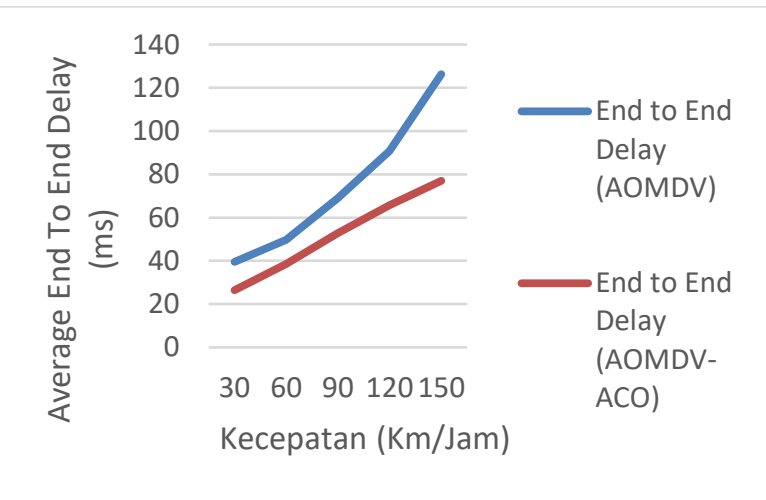

Gambar 14. Grafik Delay 100 Node

Perbandingan nilai average end to end delay pada node 50, 70 dan 100 yaitu berdasarkan grafik Gambar 12, Gambar 13 dan Gambar 14. Dapat diperoleh nilai rata-rata end to end delay pada AOMDV standar dengan 50 node yaitu sebesar 29.48072 ms. Sedangkan nilai rata-rata end to end delay pada AOMDV semut dengan 50 node yaitu sebesar $21.980328 m s$. Adapun selisih rata-rata yang diperoleh antara AOMDV standar dengan AOMDV-Semut dengan 50 node pada parameter end to end delay sebesar $7.500392 \mathrm{~ms}$. Dan nilai rata-rata end to end delay pada AOMDV standar dengan 70 node yaitu sebesar 44.52014 ms sedangkan nilai rata-rata end to end delay pada AOMDV semut dengan 70 node yaitu sebesar $36.65096 m s$. Adapun selisih rata-rata yang diperoleh antara AOMDV standar dengan AOMDV-Semut dengan 70 node pada parameter end to end delay sebesar $9.443016 \mathrm{~ms}$. Dan nilai rata-rata end to end delay pada AOMDV standar dengan 100 node yaitu sebesar 75.06622 ms. Sedangkan nilai rata-rata end to end delay pada AOMDV semut dengan 100 node yaitu sebesar $52.0818 \mathrm{~ms}$. Adapun selisih rata-rata yang diperoleh antara AOMDV standar dengan AOMDV-Semut dengan 100 node pada parameter end to end delay sebesar $22.98442 \mathrm{~ms}$. Hal ini menunjukkan bahwa implementasi algoritma semut pada protokol AOMDV menyebabkan penurunan nilai end to end delay pada protocol routing AOMDV standar. Sehingga dari hasil ujicoba yang telah dilakukan pada protokol routing AOMDV dengan menggunakan algoritma semut untuk parameter average end to end delay mampu menurunkan delay sebesar 13.3093 ms.

Pada parameter End to End Delay yaitu waktu yang dibutuhkan dalam pengiriman data dari node sumber ke node tujuan. Dalam proses pengiriman data, ada banyak faktor yang mengakibatkan terjadinya Delay. Peningkatan Delay dapat terjadi ketika jumlah komunikasi bertambah banyak (kepadatan kendaraan bertambah). Semakin padatnya kendaraan (node) dapat menyebabakn semakin banyak node perantara yang terpakai untuk mengirimkan layanan dari sumber ke tujuan, sehingga paket-paket yang dikirimkan harus melalui buffer dan menyebabkan waktu pengiriman semakin lama.

\subsection{Analisis Packet Delivery Ratio}

Packet Delivery Ratio merupakan perbandingan antara paket yang berhasil di kirim oleh node sumber dan di terima oleh node tujuan. Berikut grafik kualitas Packet Delivery Ratio dari percobaan yang telah dilakukan :

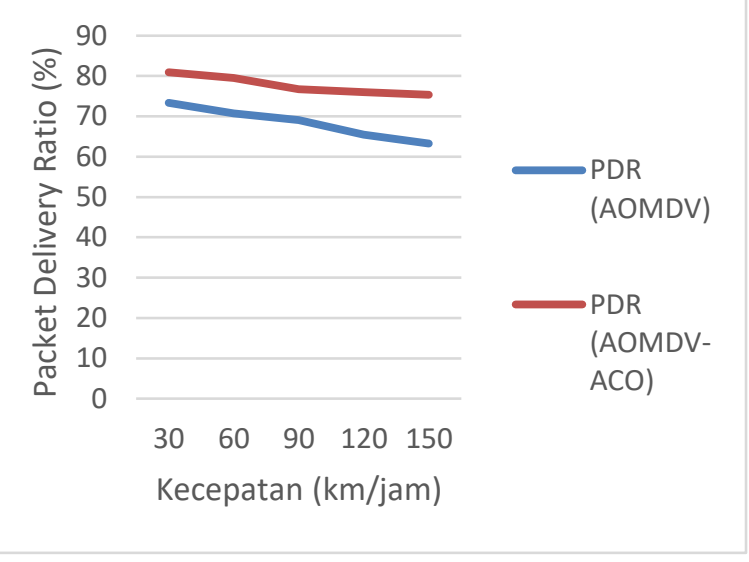

Gambar 15. Grafik PDR 50 Node 


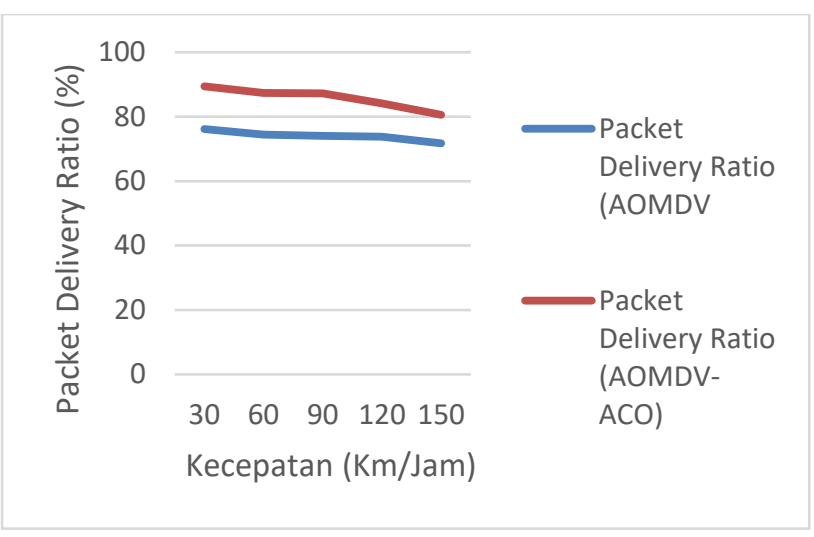

Gambar 16. Grafik PDR 70 Node

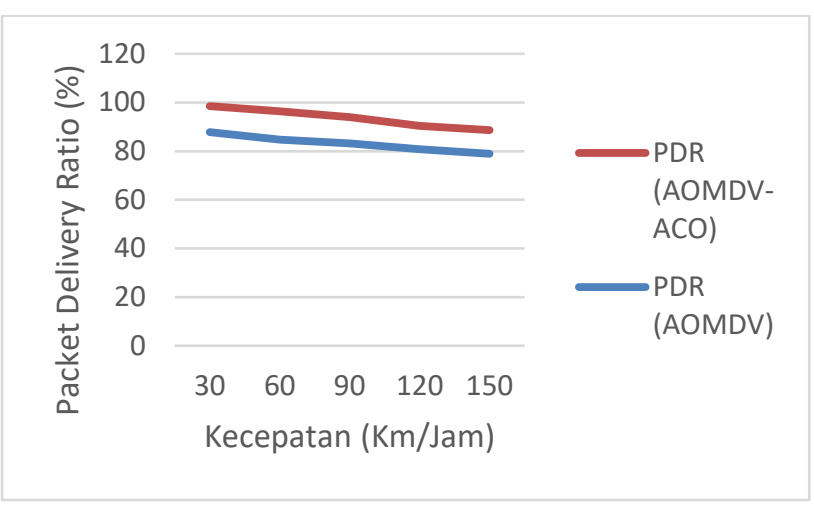

Gambar 17. Grafik PDR 100 Node

Perbandingan nilai Packet Delivery Ratio pada node 50, 70 dan 100 yaitu berdasarkan grafik Gambar 15, Gambar 16 dan Gambar 17. Dapat di peroleh jumlah rata-rata Packet delivery ratio pada AOMDV standar dengan 50 node yaitu sebesar 68.3622\%. Sedangkan jumlah rata-rata Packet delivery ratio pada AOMDV semut dengan 50 node yaitu sebesar 77.6981\%. Adapun selisih rata-rata yang diperoleh antara AOMDV standar dengan AOMDV-Semut pada parameter Packet delivery ratio dengan 50 node yaitu sebesar $9.3359 \%$. Dan jumlah rata-rata Packet delivery ratio pada AOMDV standar dengan 70 node yaitu sebesar $74.03446 \%$. Sedangkan jumlah rata-rata Packet delivery ratio AOMDV semut dengan 70 node yaitu sebesar $85.7396 \%$. Adapun selisih rata-rata yang diperoleh antara AOMDV standar dengan AOMDVSemut dengan 70 node pada parameter Packet delivery ratio sebesar $14.046168 \%$. Dan jumlah rata-rata Packet delivery ratio pada AOMDV standar dengan 100 node yaitu sebesar $83.1059 \%$. jumlah rata-rata Packet delivery ratio pada AOMDV semut dengan 100 node yaitu sebesar $93.57522 \%$. Adapun selisih rata-rata yang diperoleh antara AOMDV standar dengan AOMDVSemut pada parameter Packet delivery ratio dengan 100 node yaitu sebesar $10.46932 \%$. Hal ini menunjukkan bahwa implementasi algoritma semut pada protokol AOMDV menyebabkan peningkatan persentase Packet delivery ratio. Dari hasil ujicoba yang telah dilakukan pada protokol routing AOMDV dengan menggunakan algoritma semut mampu meningkatkan kinerja dari parameter ujicoba Packet delivery ratio sebesar $11.2838 \%$.

Pada parameter Packet Delivery Ratio (PDR) menunjukkan keberhasilan protokol dalam mengirim data, tinggi nilai Packet Delivery Ratio salah satunya disebabkan oleh berhasilnya sebuah protokol dalam melakukan pencarian dan pemeliharaan rutenya. Semakin padat jumlah node dapat diperoleh hasil yang semakin tinggi. Semakin tingginya kecepatan pergerakan node mengakibatkan semakin rendahnya Packet Delivery Ratio pada protokol AOMDV. Hal ini membuktikan bahwa semakin padatnya lingkungan simulasi yang diikuti dengan semakin lambatnya kendaraan bergerak menyebabkan rute yang terbentuk tidak cepat terputus, sehingga protokol tidak sering melakukan pembaharuan rute dan semakin sedikit terjadinya link failure maka semakin besar nilai Packet Delivery Ratio pada suatu protokol.

Berdasarkan seluruh uji coba yang dilakukan, didapatkan hasil yang menunjukkan bahwa implementasi algoritma semut pada protokol AOMDV mampu menurunkan waktu End to End Delay pada proses pengiriman data. Dan mampu meningkatkan nilai throughput dan persentase Packet Delivery Ratio. Sehingga dapat disimpulkan bahwa algoritma Semut mampu meningkatkan kinerja protokol AOMDV dengan sangat baik.

\section{KeSIMPULAN DAN SARAN}

\subsection{Kesimpulan}

Dari hasi percobaan dan analisa yang telah dilakukan, maka dapat ditarik kesimpulan sebagai berikut :

1. Pada uji coba AOMDV dengan jumlah node yang semakin banyak (50 node, 70 node 100 node) didapatkan hasil yang menunjukan bahwa semakin banyak jumlah node, maka nilai parameter throughput, Packet delivery ratio yang diperoleh semakin meningkat hal ini di sebabkan karena semakin padatnya lingkungan simulasi sehingga link tidak cepat terputus.

2. Pada avegare end to end delay semakin besar jumlah node maka semakin besar nilai yang di peroleh karena banyaknya node yang harus di lewati untuk mengirimkan paket data. 
3. Pada penelitian dilakukan 5 kali percobaan. Hasil menunjukkan bahwa uji coba yang telah dilakukan pada protocol routing AOMDV dengan menggunakan algoritma semut dapat meninggkatkan kinerja dari parameter throughput sebesar sebesar $9.7649 \mathrm{Kbps}$.

4. Untuk parameter dari Packet delivery ratio dengan menerapkan algoritma semut pada protocol routing AOMDV menunjukan hasil peningkatan dengan nilai sebesar $11.2838 \%$.

5. Sedangkan untuk parameter average end to end delay mampu menurunkan delay pada protocol routing AOMDV dengan nilai sebesar 13.3093 ms.

6. Penentuan parameter, kecepatan node, serta jumlah node serta jumlah semut pada algoritma semut yang digunakan, dapat mempengaruhi hasil optimasi pencarian rute pada protokol routing AOMDV.

\subsection{Saran}

Berdasarkan kesimpulan di atas, maka peneliti dapat memberikan saran-saran sebagai berikut:

1. Mengimplementasikan algoritma optimasi lainnya pada protokol routing AOMDV

2. Melakukan penelitian dengan menggunakan protokol routing yang berbeda pada algoritma semut.

3. Melakukan penelitian yang sama dengan mengubah parameter-parameter penelitian.

4. Berdasarkan kendala yang dialami penulis, penelitian dapat dilakukan dengan mengembangkan sendiri algoritma optimasi, sehingga dapat digunakan sesuai dengan kebutuhan dan dapat dikostumasi.

5. Untuk penelitian selanjutnya dapat digunakan whitebox testing untuk menjabarkan efisiensi rute yang di hasilkan.

\section{DAFTAR PUSTAKa}

[1] F. Nutrihadi, R. Anggoro and R. M. Ijtihadie, "Studi Kinerja VANET Scenario Generators: SUMO dan Vanet Mobisim untuk Implementasi Routing
Protocol AODV menggunakan Network Simulator 2 (NS-2)," Jurnal Teknik ITS, vol. 5, no. 1, pp. A19-A24, 2016.

[2] R. Anisia, R. Munadi and R. M. Negara, "AnalisisPerformansi Routing Protocol OLSR dan AOMDV pada Vehicular Ad Hoc Network (VANET)," Jurnal Nasional Teknik Elektro, vol. 5, no. 1, pp. 8797, 2016.

[3] A. Deshmukh and S. Dorle, "Performance Improvement of Dynamic Source Routing (DSR) Protocol using Ant Colony Optimization for Vehicular Ad-hoc Network (VANet)," International Journal of Scientific Research, vol. 5, no. 1, pp. 171-173, 2016.

[4] S. Singh, P. Kumari and S. Agrawal, "Comparative Analysis of Various Routing Protocols in VANET," International Conference on Advanced Computing \& Communication Technologies, pp. 315-319, 2015.

[5] C. Kanani and A. Sinhal, "Ant Colony Optimization based Modified AOMDV for Multipath Routing in MANET," International Journal of Computer Applications, vol. 82, no. 10, pp. 14-19, 2013.

[6] R. Chauhan and A. Dahiya, "AODV Extension using Ant Colony Optimization for Scalable Routing in VANETs," Journal of Emerging Trends in Computing and Information Sciences, vol. 3, no. 2, pp. 241-244, 2012.

[7] V. L. Ratrindra, Analisis Performansi Destination Sequenced Distance Vector (DSDV) dan Zone Routing Protocol (ZRP) Berbasis Algoritma Ant pada Jaringan Mobile Ad Hoc, Bandung: Institut Teknologi Telkom, 2010.

[8] H. E. Wahanani, "Kinerja Protokol DSR Pada Jaringan MANET dengan Metode Node Disjoint And Alternative Multipath Routing," in Seminar Nasional Teknik Informatika (SANTIKA) , Universitas Pembangunan Nasional "Veteran" Jawa Timur , 2013.

[9] R. Amalia, "Pencarian Jalur Terpendek Menggunakan Ant Colony System (Kasus: Pariwisata Kota Bogor)," Universitas Indraprasta PGRI, pp. 290304, 2015.

[10] Karjono, Moedjiono and D. Kurniawan, "Ant Colony Optimization," Jurnal TICOM, vol. 4, no. 3, pp. 119125, 2016. 